\title{
Antinociceptive, anti-inflammatory and diuretic properties of Polygonum barbatum (L.) Hara var. barbata
}

\author{
M. Abdul Mazid, ${ }^{1}$ Bidyut K. Datta, ${ }^{2}$ Lutfun Nahar, ${ }^{3}$ S. A. M. Khairul Bashar, ${ }^{4}$ \\ Sitesh C. Bachar, ${ }^{2}$ Satyajit D. Sarker ${ }^{*, 5}$ \\ ${ }^{1}$ Department of Pharmaceutical Chemistry, University of Dhaka, Dhaka 1000, Bangladesh \\ ${ }^{2}$ Department of Pharmaceutical Technology, University of Dhaka, Dhaka 1000, Bangladesh \\ ${ }^{3}$ Drug Discovery and Design Research Division, Department of Pharmacy, School of Applied Sciences, \\ University of Wolverhampton, City Campus South, MA Building, Wulfruna Street, \\ Wolverhampton WV1 1LY, England, UK \\ ${ }^{4}$ North South University, 12, Kemal Attaturk Avenue in Banani, Dhaka, Bangladesh \\ ${ }^{5}$ Department of Pharmacy, School of Applied Sciences, University of Wolverhampton, MM Building, \\ Molineux Street, Wolverhampton WV1 1SB, England, UK.
}

\begin{abstract}
RESUMO: As propriedades antinociceptiva, antiinflamatória e diurética dos extratos de $P$. barbatum (L.) Hara var. barbata, Polygonaceae, nas doses de 200 e $400 \mathrm{mg} / \mathrm{kg}$ de peso corpóreo foram avaliadas em modelos utilizando camundongos/ratos, respectivamente, o método de contorções induzidas por ácido acético, o teste de edema induzido por carragenina e o método de Lipschitz. No método de contorções induzidas por ácido acetic, todos os extratos apresentaram efeito nociceptivo dose dependente. O efeito nociceptivo mais potente foi observado com o extrato de éter de petróleo na dose de $400 \mathrm{mg} / \mathrm{kg}$ com uma inibição das contorções de 46,8\% comparado com o controle positivo de aminopirina de $62,2 \%$. O extrato de éter de petróleo na dose de 400 $\mathrm{mg} / \mathrm{kg}$ também mostrou maior atividade antiinflammatoria após $2 \mathrm{~h}$ com 39,3\% de inibição do edema de pata, e este efeito foi maior que o observado para o agente antiinflamatório convencional fenilbutazona (inibição máxima de 38,4\% após 4 h). Todos os extratos aumentaram o volume de urina de maneira dose dependente e o extrato acetato de etila mostrou um nível de significância de diurese comparável ao agente diurético padrão, furosemida.
\end{abstract}

Unitermos: Polygonum barbatum var. barbata, Polygonaceae, analgesic, antiinflammatório; diurético, modelo animal.

\begin{abstract}
The antinociceptive, anti-inflammatory and diuretic properties of the extracts of $P$. barbatum (L.) Hara var. barbata, Polygonaceae, at the doses of 200 and $400 \mathrm{mg} / \mathrm{kg}$ body weight, were evaluated in mice/rat models using, respectively, the acetic-acid-induced writhing method, the carrageenan-induced edema test and the Lipschitz method. In the acetic-acid-induced writhing test in mice, all extracts displayed a dose dependent analgesic effect. The most potent analgesic activity was observed with the petroleum ether extract at the dose of $400 \mathrm{mg} / \mathrm{kg}$ body weight with an inhibition of writhing response $46.8 \%$ compared to $62.2 \%$ for the positive control aminopyrine. Petroleum ether extract at the dose of $400 \mathrm{mg} / \mathrm{kg}$ body weight also displayed the highest levels of anti-inflammatory activity after $2 \mathrm{~h}$ with the $39.3 \%$ inhibition of paw edema, and this effect was better than the effect observed by the conventional anti-inflammatory agent phenylbutazone (maximum inhibition of $38.3 \%$ after $4 \mathrm{~h}$ ). All extracts increased urine volume in a dose-dependent manner, and the ethyl acetate extract showed a significant level of diuresis comparable to that of the standard diuretic agent furosemide.
\end{abstract}

Keywords: Polygonum barbatum var. barbata; Polygonaceae; antinociceptive; anti-inflammatory; diuretic; animal model.

\section{INTRODUCTION}

Polygonum barbatum (L.) Hara var. barbata (family Polygonaceae), common name 'bekhanjabaj', is a perennial herb found widely in marshy and aquatic places, by the sides of the rivers, seasonally flooded roadsides ditches and small ponds throughout Bangladesh, India and Thailand, and also in many other countries in the south-east Asia (Balza et al., 1989; Kirtikar \& Basu, 1999; GRIN Database, 2009). The genus Polygonum is well known for producing pharmacologically active compounds, and also for its use in the oriental traditional 
medicine systems, particularly in the treatment of pain, fever and inflammatory conditions, and as a diuretic agent. For examples, e.g. P. aviculare, P. bistorta, P. chinense, P. cuspidatum, P. glabrum, P. multiflorum, P. odoratum, $P$. orientale, $P$. perfoliatum, $P$. persicaria, $P$. tinctorium and $P$. tinctorum have been used to treat pain and fever, $P$. aviculare, $P$. barbatum, $P$. bistorta, $P$. chinense, $P$. cuspidatum, P. flaccidum, P. hydropiper, P. japonicum, $P$. lapathifolium, $P$. multiflorum, $P$. orientale, $P$. perfoliatum, P. persicaria, $P$. punctatum, $P$. sanguinaria and $P$. viviparum for inflammatory conditions, and $P$. acre, $P$. amphibium, $P$. aviculare, $P$. bistorta, $P$. cuspidatum, $P$. hydropiper, $P$. odoratum, $P$. perfoliatum, $P$. punctatum and $P$. virginianum as diuretic agents (Phytochemical and Ethnobotanical database, 2009).

To our knowledge, no pharmacological screening has ever been carried out with the extracts of $P$. barbatum var. barbata. In continuation of the bioactivity and phytochemical studies on Polygonum species (Datta et al., 2000; 2001a,b; 2002; 2004a,b; 2007), we report on the antinociceptive, anti-inflammatory and diuretic properties of the extracts of $P$. barbatum var. barbata in mice/rat models.

\section{MATERIAL AND METHODS}

\section{Plant material}

The aerial parts of Polygonum barbatum (L.) Hara var. barbata were collected from Kajla, Rajshahi, Bangladesh and authenticated by Professor Naderuzzaman (Department of Botany, University of Rajshahi, Bangladesh). A voucher specimen (BKD2004-2) representing this collection has been maintained in the Herbarium of the Department of Botany, University of Dhaka, Dhaka, Bangladesh.

\section{Extraction}

The sun-dried and ground aerial parts of $P$. barbatum var. barbata $(650 \mathrm{~g})$ were extracted with methanol (MeOH, 4 L) using maceration for five days. The extract was concentrated by evaporation under reduced pressure at $40{ }^{\circ} \mathrm{C}$. The $\mathrm{MeOH}$ extract of $P$. barbatum var. barbata was made to $90 \%$ aq. $\mathrm{MeOH}$ extract and subjected to solvent partitioning with petroleum ether (PE). The resulting aqueous $\mathrm{MeOH}$ extract was further partitioned with chloroform $\left(\mathrm{CHCl}_{3}\right)$ and finally with ethyl acetate $(\mathrm{EtOAc})$. All solvent extracts were concentrated by evaporation under reduced pressure at $40{ }^{\circ} \mathrm{C}$.

\section{Animals}

Swiss albino mice (3-4 weeks old, 20-25 g) and Long Evans adult rats (9-10 weeks old, 130-170 g) of either sex were used in this study. These experimental animals were obtained from the Animal house of the International Centre for Diarrheal Disease and Research, Bangladesh (ICDDR, B). Animals were maintained under standard environmental conditions and had free access to feed and water ad libitum. Experiments on animals were performed strictly in accordance with the guidelines provided by the Institutional Animal Ethics Committee.

Each experimental group was composed of five mice/rats. First group served as control animals, and they were treated with $1 \%$ Tween 80 in water. Second group of animals were treated with positive control. The other groups of animals were treated with the extracts at different doses (200 and $400 \mathrm{mg} / \mathrm{kg}$ ).

\section{Preparation of the extracts and positive controls}

Suspension of the extracts of $P$. barbatum var. barbata was prepared in DMSO and diluted with normal saline and triturated thoroughly, or in $1 \%$ Tween 80 in distilled water. Aminopyrine, phenylbutazone and urea (and furosemide) were used as positive controls, respectively for antinociceptive, anti-inflammatory and diuretic tests. All test samples and the positive controls were administered orally by a feeding needle.

\section{Assessment of antinociceptive activity: the acetic-acid- induced writhing method}

The antinociceptive activity of the extracts was assessed by the acetic-acid-induced writhing method (Koster et al., 1959; Whittle, 1964; Williamson et al, 1996; Zakaria et al., 2001; Silva et al., 2003) using Swiss albino mice. Experimental animals were randomly selected and divided into eight groups consisting of five mice in each group. Each group received a particular treatment i.e. Group A: control $(0.5 \mathrm{~mL}$ DMSO in $2 \mathrm{~mL}$ of normal saline), Group B: positive control (aminopyrine, $50 \mathrm{mg} /$ $\mathrm{kg}$ of body weight), Group C-E: the extracts at the dose of $200 \mathrm{mg} / \mathrm{kg}$ body weight, and Group F-H: the extracts at the dose of $400 \mathrm{mg} / \mathrm{kg}$ body weight. After $40 \mathrm{~min}$ of administration of the above treatments, each group was treated with intraperitoneally (i.p.) administered $0.7 \%$ acetic acid to induce pain sensation evident from the test animals squirming their bodies at regular time interval referred to as 'writhing'. The number of writhes (i.e., abdominal contractions and stretches) that occurred within the first 10 min following acetic acid administration were counted and recorded. Analgesic agents reduced this pain sensation which could be observed from reduced number of writhing compared to the control group. The analgesic effect of the test extracts was compared with that of the positive control aminopyrine, a well known painkiller.

\section{Assessment of anti-inflammatory activity: the carrageenan-induced edema model}


Anti-inflammatory activity of the extracts was evaluated by carrageenan-induced oedema model in Long Evans adult rats (Winter et al., 1962). In this study, edema was induced at the sub-planter region of ratios hind paw by administration of $1 \%$ carrageenan solution. The reduction of paw edema volume with the introduction of test samples would indicate anti-inflammatory activity. The edema volume was measured every hour up to several hours. The average percent decrease or increase in paw volume with time was calculated and compared against the control group. Experimental animals were randomly selected and divided into eight groups consisting of five mice in each group. Each group received a particular treatment i.e. Group A: control (1\% Tween80 in distilled water), Group B: positive control (phenylbutazone, $100 \mathrm{mg} / \mathrm{kg}$ of body weight), Group C-E: the extracts at the dose of $200 \mathrm{mg} / \mathrm{kg}$ body weight, and Group F-H: the extracts at the dose of $400 \mathrm{mg} / \mathrm{kg}$ body weight. After $30 \mathrm{~min}$ of the administration of test samples, $0.1 \mathrm{~mL}$ of $1 \%$ carrageenan in sterile saline was injected into the sub-planer surface of the right hind paw of each of rat. Paw volumes were measured up to a fixed mark by mercury displacement as viewed by travelling microscope at 1,2,3 and $4 \mathrm{~h}$ after the administration of the test samples.

\section{Assessment of diuretic property: the Lipschitz method}

Diuretic activity of the extracts was evaluated by the Lipschitz methods (1943). The diuretic action was measured as the quotient between urinary excretion by the animals treated with test samples and by the control animals, while the diuretic activity was calculated from diuretic action of the animals treated with test samples and the positive control. Test mice were grouped into nine groups, each containing five mice. Each group received a particular treatment i.e. Group A: control (0.5 mL DMSO in $2 \mathrm{~mL}$ of normal saline), Group B: positive control (urea, $500 \mathrm{mg} / \mathrm{kg}$ of body weight), Group C: standard diuretic (furosemide, $4 \mathrm{mg} / \mathrm{k}$ body weight), Group D-F: the extracts at the dose of $200 \mathrm{mg} / \mathrm{kg}$ body weight, and Group G-I: the extracts at the dose of $400 \mathrm{mg} / \mathrm{kg}$ body weight.

\section{Statistical analysis}

Statistical analysis was performed using SPSS11.5 statistical Software for Windows. Experimental values were expressed as mean \pm SEM. Independent Sample $t$-test was carried out for statistical comparison. Statistical significance was considered to be indicated by a $p$ value $<$ 0.05 in all cases.

\section{RESULTS AND DISCUSSION}

Antinociceptive, anti-inflammatory and diuretic properties of the $\mathrm{PE}, \mathrm{CHCl}_{3}$ and EtOAc extracts obtained from solvent-partitioning of the $\mathrm{MeOH}$ extract of the aerial parts of $P$. barbatum var. barbata were assessed by well established and validated experimental methods using mice and/or rat models.

In the acetic acid induced writhing test (Table 1), a dose dependent antinociceptive effect was observed with the extracts. The most potent antinociceptive activity was obtained with the petroleum ether extract at the dose of $400 \mathrm{mg} / \mathrm{kg}$ body weight with an inhibition of writhing response $46.8 \%$ compared to $62.2 \%$ for the positive control aminopyrine. The order of antinociceptive activity of the extracts was as follows: $\mathrm{PE}>\mathrm{CHCl}_{3}>$ EtOAc. As the PE extract was the most potent of three extracts, it could be assumed that the compounds responsible for the antinociceptive activity of this plant were of apolar in nature, possibly plant sterols or terpenoids. The antinociceptive property observed with the extracts of this plant was in line with the traditional use of a number of Polygonum species to treat various pains (Phytochemical and Ethnobotanical Database, 2009).

Intraperitoneal administration of acetic acid $(0.7 \%)$, a pain stimulus, produces localized inflammation by releasing the free arachidonic acid from tissue phospholipids through the action of phospholipase $\mathrm{A}_{2}$ and other acyl hydrolases (Koster et al, 1959). The synthesis of the eicosanoids from arachidonic acid incorporates the following pathways: eicosanoids with ring structures, e.g. prostaglandins, thromboxanes and prostacyclines, are synthesized via the cyclooxygenase pathway, and the hydroxylated derivatives of straight-chain fatty acids, e.g. leucotrienes, HETE (hydroxy eicosatetraenoic acids) and HPETE (hydroperoxy eicosatetraenoic acids) are synthesized via the lipooxygenase pathway. The released prostaglandins, mainly prostacyclines $\left(\mathrm{PGI}_{2}\right)$ and prostaglandin-E have been reported to be responsible for pain sensation by exciting the A $\delta$-fibers. Activity in the A $\delta$-fibers causes a sensation of sharp well localized pain. Antinociceptive activity was determined by measuring the writhing effect which was produced by administration of the acetic acid and the inhibition of writhing effect produced by the test samples. Any agent that lowers the number of writhing demonstrates analgesia by inhibiting the prostaglandin synthesis, a peripheral mechanism of pain inhibition. This hypothesis is in consonance with those authors who postulated that acetic acid induced writhing test methods are useful techniques for the evaluation of peripherally- and centrally-acting analgesic drug (Koster et al., 1959; Whittle, 1964; Williamson et al, 1996; Zakaria et al., 2001; Silva et al., 2003). Therefore, it is reasonable to assume that the antinociceptive effect of the extracts of P. barbatum var. barbata might have been mediated both peripherally and centrally.

The anti-inflammatory activity of the extracts was determined by the carrageenan-induced oedema model in Long Evans adult rats (Winter et al., 1962). Edema is a pathophysiological inflammatory condition characterized by swelling, redness, elevated temperature and pain. 
Thus, the reduction of carrageenan-induced oedema could be used as a measure of anti-inflammatory property of test samples in rat. Administration of the extracts at different doses produced significant inhibition $(p<0.05)$ of oedema within 2-3 h of carrageenan administration (Table 2). Among the extracts, the petroleum extract at the doses of 200 and $400 \mathrm{mg} / \mathrm{kg}$ body weight showed the highest levels of activity after $2 \mathrm{~h}$ with inhibition of paw oedema 28.5 and $39.3 \%$, respectively, and the latter effect was slightly better than that of the conventional antiinflammatory agent phenylbutazone (maximum inhibition of $38.3 \%$ after $4 \mathrm{~h}$ ). The anti-inflammatory property observed with the extracts of this plant was in line with the traditional use of a number of Polygonum species to treat various inflammatory diseases (Phytochemical and Ethnobotanical Database, 2009). The administration of the extracts inhibited oedema starting from the first hour and during all phases of inflammation, which was probably the inhibition of different aspects and chemical mediators of inflammation. The effect of the extracts in inflammation process induced by carrageenan suggested that the extracts might have affected the time delayed system in a similar fashion to glucocorticoids (Ahmed et al., 2005).

The diuretic activity of the extracts was assessed by the Lipschitz methods (1943). Administration of the extracts at different doses resulted in significant diuresis evident from increased urine volume (Tables 3 and 4). All extracts increased urine volume in a dose-dependent manner, and the ethyl acetate extract showed a significant level of diuresis, particularly after $2 \mathrm{~h}$ of administration (diuretic activity $=1.77$ ), which was comparable to that of the standard diuretic agent furosemide (diuretic activity = 1.72). The diuretic effect of the extracts of this plant was in line with a number of other Polygonum species known to produce diuresis (Phytochemical and Ethnobotanical Database, 2009).

The results demonstrated considerable antinociceptive, anti-inflammatory and diuretic properties of the extracts of $P$. barbatum var. barbata, which were comparable to those of the positive controls, and indicated that this plant could be a potential source for the discovery and development of newer analgesic, anti-inflammatory and diuretic 'leads' for drug development.

Table 1. Effect of Polygonum barbatum var. barbata extracts in mice observed in the acetic acid induced writhing test.

\begin{tabular}{cccccc}
\hline Group & Treatment & Dose* $(\mathrm{mg} / \mathrm{kg})$ & Mean writhing** & \% of writhing & $\begin{array}{c}\text { \% of writhing } \\
\text { Inhibition }\end{array}$ \\
\hline A & $\begin{array}{c}\text { Control: DMSO }(0.5 \mathrm{~mL}) \text { in } 2 \mathrm{~mL} \\
\text { of normal saline }\end{array}$ & - & $37.8 \pm 0.94$ & $100 \pm 3.06$ & $0 \%$ \\
B & aminopyrine & 50 & $14.3 \pm 0.74$ & $37.8 \pm 3.02$ & 62.2 \\
C & petroleum ether extract & 200 & $25.9 \pm 0.78$ & $68.5 \pm 3.00$ & 31.5 \\
D & chloroform extract & 200 & $25.40 \pm 0.82$ & $67.2 \pm 3.04$ & 32.8 \\
E & EtOAc extract & 200 & $35.6 \pm 0.89$ & $94.2 \pm 3.00$ & 5.8 \\
F & petroleum ether extract & 400 & $20.1 \pm 0.83$ & $53.2 \pm 3.00$ & 46.8 \\
G & chloroform extract & 400 & $21.3 \pm 0.64$ & $56.4 \pm 3.02$ & 43.7 \\
H & EtOAc extract & 400 & $34.69 \pm 0.88$ & $91.5 \pm 3.02$ & 8.5 \\
\hline A
\end{tabular}

*Administered orally (p.o.) $40 \mathrm{~min}$ before $0.2 \mathrm{~mL}$ of $0.7 \%$ acetic acid administration

**Counted for $10 \mathrm{~min}$, starting $10 \mathrm{~min}$ after acetic acid administration; $p<0.05$ vs. control, Student's $t$-test; values are mean $\pm \mathrm{SE}$ $(\mathrm{N}=5)$.

Table 2. Effect of Polygonum barbatum var. barbata extracts in rats observed in the carrageenan-induced edema test.

\begin{tabular}{ccccccc}
\hline \multirow{2}{*}{ Group } & Treatment & Dose & \multicolumn{4}{c}{ Oedema volume $(\mu \mathrm{L})(\%$ inhibition $)$} \\
\cline { 3 - 7 } & & $(\mathrm{mg} / \mathrm{kg}, p . o)$. & $1 \mathrm{~h}$ & $2 \mathrm{~h}$ & $3 \mathrm{~h}$ & $4 \mathrm{~h}$ \\
\hline A & Control $(1 \%$ aq. Tween 80$)$ & $10 \mathrm{~mL} / \mathrm{kg}$ & $36.4 \pm 2.15$ & $64.6 \pm 2.69$ & $71.4 \pm 0.83$ & $63.0 \pm 1.26$ \\
B & phenylbutazone & $100(i . p)$. & $27.2 \pm 0.79(24.4)$ & $42.4 \pm 1.86(34.7)$ & $45.2 \pm 1.94(36.7)$ & $38.6 \pm 0.76(38.3)$ \\
C & petroleum ether extract & 200 & $32.2 \pm 0.77(9.9)$ & $46.2 \pm 0.87(28.5)$ & $54.0 \pm 1.12(24.4)$ & $56.2 \pm 1.31(10.8)$ \\
D & chloroform extract & 200 & $28.6 \pm 1.43(21.4)$ & $47.0 \pm 1.02(27.2)$ & $57.8 \pm 1.73(19.0)$ & $57.0 \pm 1.72(9.5)$ \\
E & EtOAc extract & 200 & $34.6 \pm 1.93(4.9)$ & $59.2 \pm 1.31(8.2)$ & $66.4 \pm 1.22(7.0)$ & $61.4 \pm 1.56(2.5)$ \\
F & petroleum ether extract & 400 & $31.0 \pm 0.89(14.8)$ & $39.2 \pm 1.21(39.3)$ & $48.2 \pm 1.25(32.4)$ & $53.6 \pm 1.31(14.9)$ \\
G & chloroform extract & 400 & $27.4 \pm 1.37(25.0)$ & $45.8 \pm 1.58(29.1)$ & $56.0 \pm 2.34(21.6)$ & $56.0 \pm 2.34(14.0)$ \\
H & EtOAc extract & 400 & $32.6 \pm 1.32(10.4)$ & $58.6 \pm 1.12(9.2)$ & $65.4 \pm 1.22(8.4)$ & $60.4 \pm 1.06(4.1)$ \\
\hline
\end{tabular}

The initial hind paw volume of the rat was determined volumetrically. Each point represents the mean $\pm \mathrm{SEM}$ of five rats. $p<0.05$, compared with the control group (Student's $t$-test).

Inhibition $(\%)=100(1-(\mathrm{a} / \mathrm{b}))$

Where $\mathrm{a}=$ mean paw volume of treated animals after carrageenan injection; $\mathrm{b}=$ mean paw volume of control animals after carrageenan injection 
Table 3. Effect of Polygonum barbatum var. barbata extracts on urination volume in mice.

\begin{tabular}{|c|c|c|c|c|c|c|c|}
\hline \multirow{2}{*}{ Group } & \multirow{2}{*}{ Treatment } & \multirow{2}{*}{$\begin{array}{c}\text { Dose } \\
(\mathrm{mg} / \mathrm{kg}, p . o)\end{array}$} & \multicolumn{5}{|c|}{ Volume of urine in $\mathrm{mL}$ (cumulative) } \\
\hline & & & $1 \mathrm{~h}$ & $2 \mathrm{~h}$ & $3 \mathrm{~h}$ & $4 \mathrm{~h}$ & $5 \mathrm{~h}$ \\
\hline A & Control: $0.5 \mathrm{~mL}$ DMSO in $2 \mathrm{~mL}$ of normal saline & - & 2.1 & $1.8(3.9)$ & $0.6(4.5)$ & $--(4.5)$ & $0.5(5.0)$ \\
\hline $\mathrm{B}$ & urea & 500 & 2.8 & $1.8(4.6)$ & $1.5(6.1)$ & $1.0(7.1)$ & $0.3(7.4)$ \\
\hline $\mathrm{C}$ & furosemide & 3.0 & 3.8 & $3.1(6.9)$ & $2.3(9.3)$ & -- $(9.3)$ & $0.2(9.9)$ \\
\hline $\mathrm{D}$ & petroleum ether extract & 200 & 2.2 & $1.0(3.2)$ & $1.5(4.7)$ & $--(4.7)$ & $0.4(5.1)$ \\
\hline $\mathrm{E}$ & chloroform extract & 200 & 2.0 & $0.8(2.8)$ & $1.4(4.2)$ & $0.2(4.4)$ & $0.0(4.4)$ \\
\hline $\mathrm{F}$ & EtOAc extract & 200 & 2.4 & $2.1(4.5)$ & $1.6(6.1)$ & $0.8(6.9)$ & $0.0(6.9$ \\
\hline G & petroleum ether extract & 400 & 2.6 & $2.5(5.1)$ & $1.8(6.9)$ & $1.2(8.1)$ & $0.5(8.6)$ \\
\hline $\mathrm{H}$ & chloroform extract & 400 & 2.8 & $2.4(5.2)$ & $2.0(7.2)$ & $1.2(8.4)$ & $0.3(8.7)$ \\
\hline I & EtOAc extract & 400 & 3.0 & $3.2(6.2)$ & $3.6(9.8)$ & $1.0(10.8)$ & $0.2(11.0)$ \\
\hline
\end{tabular}

-- = No urine volume

Table 4. Diuretic activity of Polygonum barbatum var. barbata extracts in mice.

\begin{tabular}{|c|c|c|c|c|c|c|c|}
\hline \multirow{2}{*}{ Group } & \multirow{2}{*}{ Treatment } & \multirow{2}{*}{$\begin{array}{c}\text { Dose } \\
(\mathrm{mg} / \mathrm{kg}, p . o)\end{array}$} & \multicolumn{5}{|c|}{ Volume of urine in $\mathrm{mL}$ (cumulative) } \\
\hline & & & $1 \mathrm{~h}$ & $2 \mathrm{~h}$ & $3 \mathrm{~h}$ & $4 \mathrm{~h}$ & $5 \mathrm{~h}$ \\
\hline $\mathrm{B}$ & urea & 500 & $1.33 *$ & $1.00 *$ & $2.50 *$ & $1.00 *$ & $0.60 *$ \\
\hline $\mathrm{C}$ & furosemide & 3.0 & $1.81 *(1.36)$ & $1.72 *(1.72)$ & $3.83 *(1.53)$ & -- & $0.40 *(0.66)$ \\
\hline $\mathrm{D}$ & petroleum ether extract & 200 & $1.05^{*}(0.79)$ & $0.55 *(0.55)$ & $2.50 *(1.00)$ & -- & $0.80 *(1.33)$ \\
\hline $\mathrm{E}$ & chloroform extract & 200 & $0.95 *(0.71)$ & $0.44 *(0.44)$ & $2.33 *(0.93)$ & $0.20 *(0.2)$ & -- \\
\hline $\mathrm{F}$ & EtOAc extract & 200 & $1.14 *(0.85)$ & $1.16 *(1.16)$ & $2.66^{*}(1.06)$ & $0.80 *(0.80)$ & -- \\
\hline $\mathrm{G}$ & petroleum ether extract & 400 & $1.24 *(0.93)$ & $1.39 *(1.39)$ & $3.00 *(1.20)$ & $1.20 *(1.20)$ & $1.00 *(1.66)$ \\
\hline $\mathrm{H}$ & chloroform extract & 400 & $1.33 *(1.00)$ & $1.33 *(1.33)$ & $3.33 *(1.33)$ & $1.20 *(1.20)$ & $0.60 *(1.00)$ \\
\hline I & EtOAc extract & 400 & $1.43 *(1.07)$ & $1.77 *(1.77)$ & $6.00 *(2.40)$ & $1.00 *(1.00)$ & $0.40 *(0.66)$ \\
\hline
\end{tabular}

$*$ Diuretic action $=($ volume of urine for test sample-treated mice $) /($ volume of urine for control mice $)$

The values in parentheses indicate diuretic action which is (diuretic action of test sample treated mice)/(diuretic action of ureatreated mice)

-- = No urine volume

\section{REFERENCES}

Ahamed KFHN, Kumar V, Raja S, Mukherjee K, Mukherjee PK 2005. Antinociceptive and anti-inflammatory activity of Aaraucaria bidwillii Hook. Iranian J Pharmacol Ther 4: 105-109.

Balza F, Abramowski Z, Towers GHN, Wiriychitra P 1989. Identification of proanthocyanidin polymers as the piscicidal constituents of Mammea siamensis, Polygonum stagninum and Diospyros diepenhorstii. Phytochemistry 28: 1827-1830.

Datta BK, Datta SK, Rashid MA, Nash RJ, Sarker SD 2000. A sesquiterpene acid and flavonoids from Polygonum viscosum. Phytochemistry 54: 201-205.

Datta BK, Rashid MA, Kundu JK, Rouf ASS, Sarker SD, Datta SK 2001a. Isolation and structure elucidation of viscoazucine, a novel sesquiterpene from Polygonum viscosum. Pharmazie 56: 578-579.

Datta BK, Rashid MA, Datta SK, Sarker SD 2001b. Viscozulenic acid: A novel sesquiterpene acid from Polygonum viscosum. Pharm Biol 39: 198-201.

Datta BK, Datta SK, Rashid MA, Sarker SD 2002. Flavonoids from Polygonum stagninum (Polygonaceae). Biochem Syst Ecol 30: 693-696.

Datta BK, Datta SK, Khan TH, Kundu JK, Rashid MA, Nahar L, Sarker SD 2004a. Anti-cholinergic, cytotoxic and antiHIV-1 activities of sesquiterpenes and a flavonoid from Polygonum viscosum. Pharm Biol 42: 18-23.

Datta BK, Datta SK, Chowdhury MM, Khan TH, Kundu JK, Rashid MA, Nahar, L, Sarker SD 2004b. Analgesic, anti-inflammatory and CNS depressant activities of sesquiterpenes and a flavonoid glycoside from Polygonum viscosum. Pharmazie 59: 222-225.

Datta BK, Nahar L, Rahman MM, Gray AI, Auzi AA, Sarker SD 2007. Polygosumic acid, a new cadinane sesquiterpene, from Polygonum viscosum inhibits the growth of drugresistant Escherichia coli and Staphylococcus aureus (MRSA) in vitro. J Nat Med 61: 391-396.

GRIN Database 2009. USDA, ARS, National Genetic Resources Program, Germplasm Resources Information Network 
- (GRIN) [Online Database], National Germplasm Resources Laboratory, Beltsville, Maryland. Available on-line at: http://www.ars-grin.gov/cgi-bin/npgs/html/ taxon.pl?448854

Kiritikar KR, Basu BD 1999. Indian Medicinal Plants, $2^{\text {nd }}$ edition, Allahabad, India.

Koster R, Anderson M, De-Beer EJ 1959. Acetic acid for analgesic screening. Fed Proceedings 18: 412-418.

Lipschitz WL, Hadidian Z, Kerpesar A 1943 Bioassay of diuretics. J Pharmacol Exp Ther 79: 97-110.

Phytochemical and Ethnobotanical Databases 2009. Dr Duke's Phytochemical and Ethnobotanical Databases, USA. Available on-line at http://www.ars-grin.gov/duke/

Silva J, Abebe W, Sousa SM, Duarte VG, Machado MI, Matos FJ 2003. Analgesic and anti-inflammatory effects of essential oils of Eucalyptus. J Ethnopharmacol 89: 277 283.

Whittle BA 1964. The use of changes in capillary permeability in mice to distinguish between narcotic and non-narcotic analgesics. Br J Pharmacol Chemother 22: 246-253.

Williamson EM, Okpako DT, Evans FJ 1996. Pharmacological methods in phytotherapy research. In: Selection, Preparation and Pharmacological Evaluation of Plant Materials, vol. 1. John Wiley, Chichester; pp. 184-186.

Winter CA, Risley EA, Nuss GW 1962. Carrageenan-induced edema in the hind paw of rat as an assay for antiinflammatory drugs. Proc Soc Biol Med 11: 544-47.

Zakaria MN, Islam MW, Radhakrishnan R, Chen HB, Kamil M, Al-Gifri AN, Chan-Attas A 2001. Antinociceptive and anti-inflammatory properties of Caralluma arabi. $J$ Ethnopharmacol 76: 155-58. 